Génét. Sél. Evol., 1985, 17 (3), 359-368

\title{
On the genetic determinism of muscular hypertrophy in the Belgian White and Blue cattle breed \\ I. Experimental data ${ }^{(*)}$
}

\author{
R. HANSET and C. MICHAUX \\ Faculté de Médecine vétérinaire (U.LG) \\ 45, rue des Vétérinaires, B-1070 Bruxelles, Belgique
}

\begin{abstract}
Summary
The inheritance of muscle hypertrophy has been studied in an experiment where $F_{1}$ cows (Belgian Blue $\times$ Friesian) are backcrossed to Belgian Blue sires. The total weight of the most important muscles, in calves slaughtered at the constant weight of $84 \mathrm{~kg}$, was the criterion for muscle development. The distribution of this variable in the backeross shows a clear bimodality corresponding to the segregation of 2 alleles, in equal proportions.

The fitting of a monogenic model, by the Weighted Least Squares method, has led to the estimations of gene effect and dominance deviation. The difference between the 2 homozygotes amounts to more than 6 times the standard deviation within genotype. It is concluded that a major gene is involved in the determination of muscle hypertrophy in the Belgian Blue cattle breed and that regarding the phenotypic expression considered in this study this gene behaves as a partially recessive gene, the heterozygote being near the homozygous normal. The symbol $m h$ for muscular hypertrophy is proposed to identify this major gene.
\end{abstract} cattle.

Key words : Belgian White and Blue breed, muscle hypertrophy, inheritance, major gene,

\section{Résumé}

Le déterminisme génétique de l'hypertrophie muscu'aire dans la race bovine Blanc-Bleu Belge. I. - Données expérimentales

L'hérédité de l'hypertrophie musculaire est étudiée dans une expérience où des vaches $F_{1}$, issues de taureaux de race Blanc-Bleu Belge et de vaches Frisonnes sont croisées en retour à des taureaux de race Blanc-Bleu Belge.

Le critère de développement musculaire a été le poids total des muscles les plus plus importants obtenu sur des veaux abattus au poids constant de $84 \mathrm{~kg}$. La distribution de cette variable dans le croisement de retour est nettement bimodale ce qui correspond à la

* This work is supported by the \& Institut pour l'Encouragement de la Recherche Scientifique dans l'Industrie et l'Agriculture »(I.R.S.I.A.). 
ségrégation, en proportions égales, d'une paire d'allèles. L'ajustement d'un modèle monogénique par la méthode des moindres carrés pondérés a conduit à l'estimation de l'effet du gène et de la déviation de dominance. La différence entre homozygotes s'élève à plus de 6 fois la déviation standard « intra-génotype ». On en conclut qu'un gène majeur est impliqué dans la détermination de l'hypertrophie musculaire dans la race Blanc-Bleu Belge et que, pour le critère utilisé, ce gène se comporte comme un récessif partiel, l'hétérozygote étant plus près de l'homozygote normal. Le symbole $m h$ est proposé pour identifer ce gène majeur. bovin.

Mots clés : Race Blanc-Bleu Belge, hypertrophie musculaire, hérédité, gène majeur,

\section{Introduction}

The genetic determinism of muscle hypertrophy in cattle has been considered according to the authors, as due either to one single gene (dominant complete or partial, recessive complete or partial) or to more than one gene (see the review by Menissier, 1982). On the other hand, in most of the genetic analyses of this condition so far published, the distribution of the animals into phenotypic classes was based on a subjective appraisal of the conformation.

In the experiment we report in this paper, the degree of muscling was evaluated by the total weight of the most important muscles. So in this study, a well defined phenotype, measured on a metric scale, replaces a sometimes ambiguous phenotypic trait.

The proof of the segregation of a major gene, if any, would then be the straightforward outcome of the inspection of the distribution of this quantitative variable considered as an expression of the muscle hypertrophy. Furthermore, estimations of the gene effect and of the dominance deviation for this phenotypic criterion are then possible through the fitting of the appropriate mathematical model. Partial accounts of this experiment have been presented earlier (HANSET, $1982 \mathrm{a}, \mathrm{b}$ ).

\section{Material and methods}

The calves of both sexes were reared on the same diet (milk from the bucket) till the final weight of $84 \mathrm{~kg}$. They were then slaughtered and the halfcarcasses dissected. The average final weight was in fact $83.9 \mathrm{~kg}(\mathrm{~S}=4.0)$ and the final age 82.1 days $(\mathrm{S}=25.3)$.

These calves belonged to the following genetic types :

1) dairy (European Friesian) - D - $(n=5)$;

2) double-muscled (Belgian White and Blue) - DM- $(\mathrm{n}=30)$, born from double-muscled cows bred to 3 double-muscled A.I. sires (from sire De, $n=10$; from sire $\mathrm{Na}, \mathrm{n}=8$; from sire $\mathrm{Te}, \mathrm{n}=12$ );

3) first-cross $-\mathrm{F}_{1}-(\mathrm{n}=7)$; born from Friesian cows bred to sire De;

4) backcross $-B C-(n=60) ; F$. cows (14 daughters of sire De and 20 daughters of sire $\mathrm{Te}$ ) were bred to their respective fathers $\mathrm{De}(\mathrm{n}=21)$ and $\mathrm{Te}(\mathrm{n}=23)$ and to 2 other double-muscled bulls : $\mathrm{Na}(\mathrm{n}=12)$ and $\mathrm{Ch}(\mathrm{n}=4)$. 
All these sires belonged to the Belgian White and Blue breed and are of the double-muscled type. These $F_{1}$ cows had a typical dual-purpose phenotype. The calves from the sires $\mathrm{De}$ and $\mathrm{Na}$ were dissected between 1972 and 1978 and the calves from the sires $\mathrm{Te}$ and $\mathrm{Ch}$ between 1979 and 1984. The calves were reared in the constant environment of an experimental station, throughout the entire period.

The muscling criterion is the sum of the weights (in the left half-carcass) of the most significant muscles, their share in the whole musculature amounting to 75 p. 100 approximately. Each total muscle weight was adjusted to a common final weight of $84 \mathrm{~kg}$.

The following muscles or groups of muscles are included in this sum :

- Neck region : Rhomboideus, Splenius, Semispinalis capitis, Spinalis dorsi, Longissimus dorsi.

- Thorax region : Latissimus dorsi, Pectorales superficialis et profundi, Serratus ventralis.

- Thoracic limb : Supraspinatus, Infraspinatus, Teres minor, Deltoideus, Subscapularis, Teres major, Biceps brachii, Brachialis, Triceps brachii (caput longum, laterale), Antebrachii.

- Pelvic limb : Gluteus medius, Tensor fasciae latae, Biceps femoris, Vastus lateralis, Rectus femoris, Vastus medialis, Semitendinosus, Sartorius, Gracilis, Semimembranosus, Pectineus, Adductor femoris, Gastrocnemius, Extensor group, Flexor group, Psoas major, Psoas minor, lliacus.

A detailed study of the hypertrophy of single muscles will be presented in an independent paper.

The data of both sexes were pooled. There was no difference between sexes regarding the total muscle weight, as a consequence of the constraint of the common final weight. The normality of the frequency distributions was tested by the KolmoGOROV-SMIRNOV procedure D (Durbin's version) for samples of size greater than 50 and by the W test (ShapIRo \& WILK, 1965) for samples of size smaller than 50, this latter test being in this instance more powerful than the former (STEPHENS, 1974).

The Statistical Analysis System (SAS) package was used to perform these tests. The homogeneity of variance was tested by the Bartlett's test (SNEDECor \& CocHRAN, 1980).

On the other hand, in the case of the backcross data, the sample obtained can be considered as a random sample of a mixture with proportions $p$ and $q$ of two univariate normal distributions with means $\mu_{1}$ and $\mu_{2}$ and a common variance $\sigma^{2}$.

The likelihood of the sample of size $\mathrm{n}$ is given by :

$$
\begin{gathered}
\mathrm{L}=\underset{i=1}{\pi}\left(\mathrm{p} \mathrm{Z} \mathrm{Z}_{1}^{i}+\mathrm{q} \mathrm{Z}_{2}\right) \\
\text { with } \mathrm{Z}^{i}=\frac{1}{\sigma \sqrt{2 \pi}} \operatorname{exp.}\left[-(\mathrm{X}-\mu)^{2 / 2} \sigma^{2}\right]
\end{gathered}
$$


The log-likelihood of the sample becomes :

$$
\begin{aligned}
\log \mathrm{L}= & \sum_{\mathrm{i}=1}^{\mathrm{n}} \ln \left(\mathrm{p} \mathrm{Z}_{1}^{i}+\mathrm{q} \mathrm{Z}_{2}^{i}\right) \\
= & -\frac{\mathrm{n}}{2} \ln 2 \pi-\frac{\mathrm{n}}{2} \ln \sigma^{2}+\sum_{\mathrm{i}=1}^{\mathrm{n}} \ln \left\{\mathrm{p} . \exp \left[-\left(\mathrm{X}_{i}-\mu_{1}\right)^{2 / 2} \sigma^{2}\right]\right. \\
& \left.+\mathrm{q} . \exp \left[-\left(\mathrm{X}_{i}-\mu_{2}\right)^{2 / 2} \sigma^{2}\right]\right\} .
\end{aligned}
$$

The combination of estimates $\left(\mu_{1}, \mu_{2}, \sigma^{2}, p\right)$ which maximizes the log-likelihood function is found iteratively. To this end, the Maximum Likelihood Estimation Program of KAPLAN \& Elston (1978) was used.

\section{Results and discussion}

Table 1 gives, for each genetic type, the sample size, the mean, the standard deviation and for the larger classes, a test of normality of the muscling criterion defined above.

\section{TABLE 1}

Mean, $\bar{x},(\mathrm{~kg})$ and standard deviation, $S$, of the total muscle weight for the different genetic classes.

\begin{tabular}{|c|c|c|c|c|}
\hline Genetic type & $\mathbf{n}$ & $\overline{\mathbf{x}}$ & $\mathbf{S}$ & Test of Normality \\
\hline $\mathbf{D} \ldots \ldots \ldots \ldots$ & 5 & 12.357 & 0.548 & \\
\hline DM $\ldots \ldots \ldots$ & 30 & 18.336 & 0.791 & (W) $\mathrm{P}<0.063$ \\
\hline$F_{1} \ldots \ldots \ldots$ & 7 & 14.312 & 0.920 & \\
\hline $\mathbf{B C} \ldots \ldots \ldots \ldots$ & 60 & 16.608 & 1.977 & (D) $\mathrm{P}<0.01$ \\
\hline BC $1 \ldots \ldots \ldots$ & 28 & 14.685 & 0.969 & (W) $\mathrm{P}<0.018$ \\
\hline BC $2 \ldots \ldots \ldots$ & 32 & 18.290 & 0.600 & (W) $\quad \mathrm{P}<0.324$ \\
\hline
\end{tabular}

Moyenne, $\bar{x},(\mathrm{~kg})$ et déviation standard, $S$, du poids total des muscles des différentes classes génétiques.

$\left[D=\right.$ dairy,$\quad D M=$ double-muscled, $F_{1}=$ first cross $D M \times D ; B C=$ backcross ; (D) test ; (W) test].

The distribution of the total muscle weight is graphed in figure $1:$ A) for the calves born from double-muscled parents $(\mathrm{DM} \times \mathrm{DM}) ; \mathrm{B})$ for the calves born from the backcross to the double-muscled parent $\left(D M \times F_{1}\right)$.

Bimodality is very obvious for the results of the backcross. It is expressed in a large standard deviation and a highly significant test of normality. As a consequence, this distribution can be resolved into 2 distributions, either visually or by the fitting of 2 normal distributions by a maximum likelihood procedure. Both approaches lead to the same result. Considering figure 1, the cut-off point is lying between 16 and 
A

\section{DM $\times$ DM}
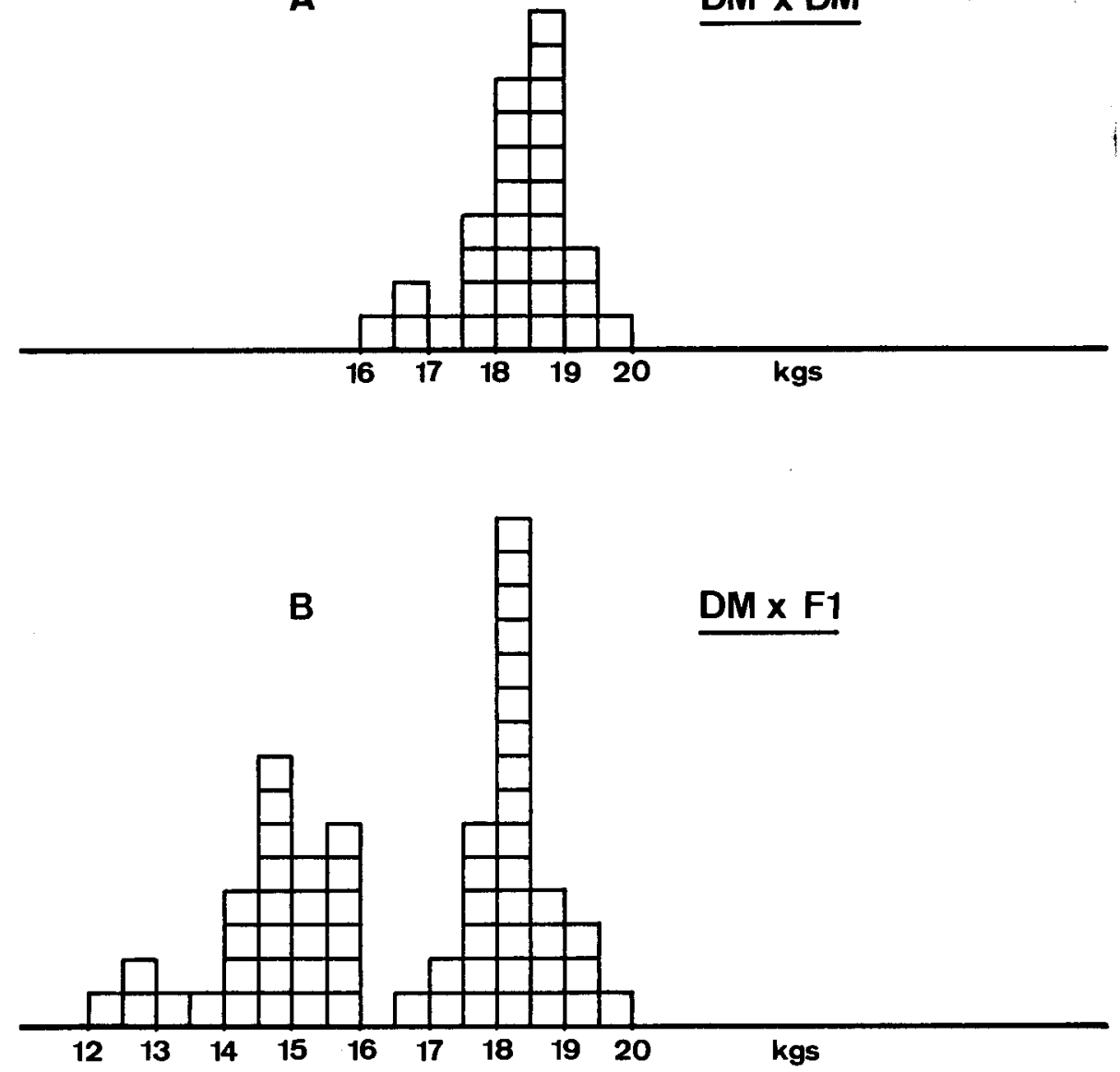

FIG. 1

Distributions of the muscle weight in the offspring :

A) of double-muscled parents (DM $\times D M)$;

$B)$ of the backcross of $F_{1}$ cows to double-muscled bulls $\left(D M \times F_{1}\right)$,

(one square $=$ one individual).

Distributions du poids des muscles dans la descendance :

A) des parents culards $(D M \times D M)$;

B) du Backross des vaches $F_{1}$ avec des taureaux culards $\left(D M \times F_{1}\right),(1$ carré $=1$ individu $)$. 
$17 \mathrm{~kg}$. The mean, the standard deviation and the test of normality of the 2 component distributions are given in table 1 where they are referred to as BC 1 and $\mathrm{BC} 2$. The non-normality in $\mathrm{BC} 1$ is due to 5 weakened animals, which reached the final weight at the average age of 116 days, far above the mean of 82 days. If the 2 observed variances for $\mathrm{BC} 1$ and $\mathrm{BC} 2$ are significantly different, nevertheless, the test of homogeneity of variance applied to the five estimates (D, DM, F,$B C 1$ and $\mathrm{BC} 2)$ is not significant $(0.25>\mathrm{P}>0.10)$. Therefore, a common variance is admitted for $\mathrm{BC} 1$ and $\mathrm{BC} 2$ and below for the five classes.

On the other hand, the maximum likelihood estimates and their standard errors are :

$$
\begin{gathered}
\mu_{1}=14.689( \pm 0.152) ; \mu_{2}=18.285( \pm 0.143) ; \\
\sigma^{2}=0.626( \pm 0.120) ; p=0.4664( \pm 0.065)
\end{gathered}
$$

The antimode of this compound distribution is halfway between the 2 means, $\mu_{1}$ and $\mu_{2}$ and equal to $16.487 \mathrm{~kg}$. The $\mathrm{BC} 1$ and $\mathrm{BC} 2$ means compare very well with the $F_{1}$ and DM means respectively (tabl. 1).

As indicated above, the data of both sexes were pooled. The data were also pooled over years and the reason is found in figure 2 which shows the yearly

\begin{tabular}{|c|c|c|c|c|c|c|c|c|c|c|c|c|c|}
\hline & $\sqrt{3}$ & & 5 & 1 & 5 & 0 & ? & $?$ & ? & 0 & ? & 0 & $\frac{\text { total }}{30}$ \\
\hline 2..... & 1 & 3 & 5 & 5 & 3 & 1 & 0 & 1 & 1 & 2 & 6 & 4 & 32 \\
\hline C1 & 0 & 3 & 4 & 3 & 1 & 2 & 0 & 2 & 1 & 3 & 5 & 4 & 28 \\
\hline
\end{tabular}
variation of the average total muscle weight for the 3 classes : DM, BC 2 and $\mathrm{BC} 1$.

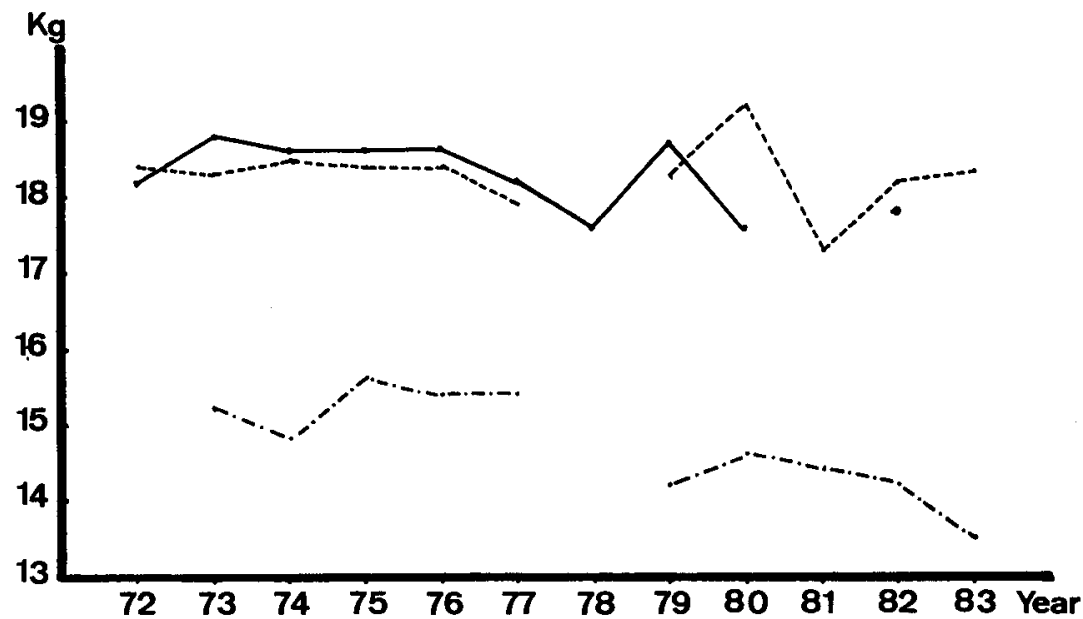

FIG. 2

Yearly variation of the adjusted means of total muscle weight for the 3 classes : $D M, B C 1$ and $B C 2$ (and samples size).

Variation annuelle des moyennes du poids total des muscles ajusté et taille des échantillons pour les 3 classes : DM, BC 1 et BC 2. 
Bimodality is apparent because the difference between the 2 subpopulation means is greater than 4 times the common standard deviation and this is far more than the minimum requirement of 2 standard deviations (Merat, 1967, 1968). The 2 distributions are the expression of the segregation in equal proportions of a single pair of genes as in the classical backcross to the recessive parent. It seems therefore quite reasonable to consider these 2 subpopulations as 2 genetic classes.

As no single symbol was agreed upon until now to identify this gene, we propose the symbol $m h$ for muscular hypertrophy and + for the normal allele. Accordingly, the 3 genotypes at the $m h$ locus are written as follows : $m h / m h ; m h /+;+1+$.

If the segregation of a single major gene is admitted, the question is then to know whether the gene for double-muscling is completely recessive or not. The gene effect and the dominance deviation were estimated through the fitting to the data of a monogenic model. Regarding their degree of muscling, the 2 breeds used in this cross - the Friesian (D) and the Belgian White and Blue (DM) - could differ not only for the gene for muscle hypertrophy but also for polygenes. Bearing this in mind, one can write down the expectations corresponding to the genetic types (tabl. 2).

The breed difference is written :

$$
\mathrm{DM}-\mathrm{D}=2 \mathrm{~m}+2 \mathrm{a},
$$

2 a stands for the difference in muscling between the genotypes $m h / m h$ and $+/+$ and $2 \mathrm{~m}$ for the difference due to polygenes.

The expectation for the $F_{1}$ mean is equal to :

$$
\mu+\mathrm{d} \text {, with } \mathrm{d} \text { for the dominance deviation. }
$$

\section{TABLE 2}

Weighted least squares solutions and their standard errors.

Observed and expected means of the total muscle weight $(\mathrm{kg})$ for the different genetic classes.

Solutions moindres carrés pondérés et leurs erreurs standard. Moyennes observées et attendues du poids total des muscles ( $\mathrm{kg}$ ) des différentes classes génétiques.

\begin{tabular}{c|c|c}
\hline $\begin{array}{c}\mu=15.369 \\
\mathrm{a}=2.746 \quad( \pm 0.189) \\
( \pm 0.352)\end{array}$ & $\begin{array}{c}\mathrm{m}=0266 \\
\mathrm{~d}=-0.865\end{array}$ \\
\multicolumn{2}{c|}{$\begin{array}{c}( \pm 0.345) \\
( \pm 0.291)\end{array}$} \\
\hline Expectations & $\begin{array}{c}\text { Observed means } \\
(\mathrm{kg})\end{array}$ & $\begin{array}{c}\text { Expected means } \\
(\mathrm{kg})\end{array}$ \\
\hline $\mathrm{D}=\mu-\mathrm{m}-\mathrm{a}$ & 12.357 & 12.357 \\
$\mathrm{DM}=\mu+\mathrm{m}+\mathrm{a}$ & 18.336 & 18.381 \\
$\mathrm{~F}_{1}=\mu+\mathrm{d}$ & 14.312 & 14.504 \\
$\mathrm{BC} 1=\mu+\mathrm{m} / 2+\mathrm{d}$ & 14.685 & 14.637 \\
$\mathrm{BC} 2=\mu+\mathrm{m} / 2+\mathrm{a}$ & 18.290 & 18.248 \\
\hline
\end{tabular}

$\left[D=\right.$ dairy $; \mathrm{DM}=$ double-muscled $; \mathrm{F}_{1}=$ first cross $\mathrm{DM} \times \mathrm{D} ; \mathrm{BC}=$ backcross $]$. 
The Weighted Least Squares equations leading to the estimations of the elements of the model are given in the appendix. The Weighted Least Squares solutions and their standard errors are given in table 2 as well as the observed and the expected means.

The - $m$ - effect of the model is positive but not significantly different from zero. This result is unexpected but the non-significance is probably due to the small size of the samples. On the other hand, the $-\mathrm{a}-$ and - $\mathrm{d}-$ effects are significant. Since, the $F_{1}$ cows were daughters of only 2 sires, some confounding is possible. Moreover, these estimates concern a particular criterion, the total muscle weight, measured at a given age for a given rearing system.

Nevertheless, one may safely conclude that, for the criterion of muscling used in this study, the major gene for muscle hypertrophy behaves as a partially recessive gene, the first copy of the $m h$ gene having a distinctly smaller effect than both copies (fig. 3).

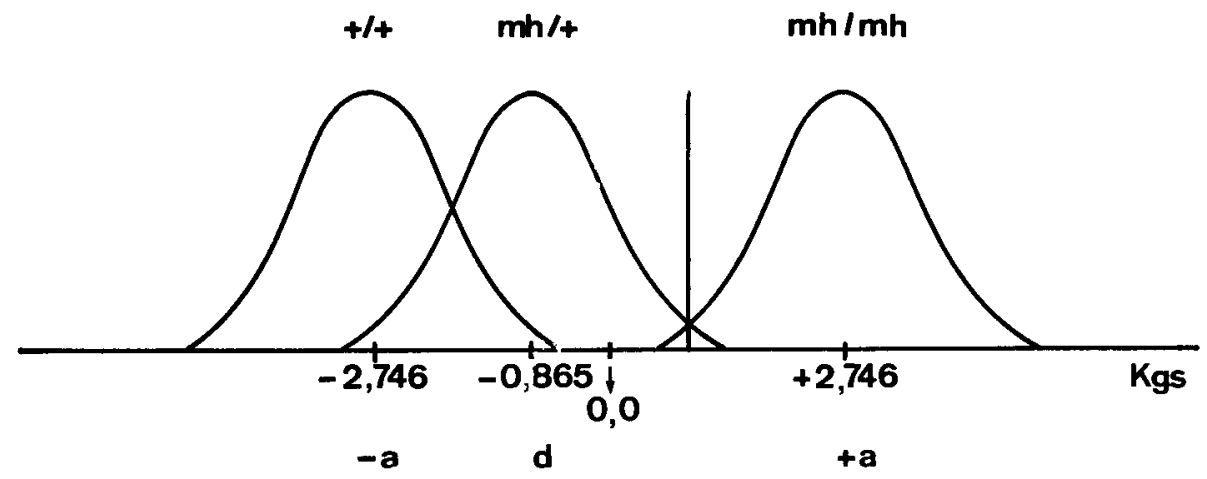

Fig. 3

The relative positions of the 3 genotypes $(++, m h /+, m h / m h)$ at the $m h$ locus according to the estimates of the gene effects

$(|a|:$ genotypic value of the homozygote and $d:$ dominance deviation) and of the common standard deviation $(0.79 \mathrm{~kg})$.

The vertical line separates the normal conformation (at the left) from the double-muscled conformation (at the right).

Positions relatives des 3 génotypes $(++; m h /+; m h / m h)$ au locus $m h$ selon les estimations des effets du gène $(|a|:$ valeur génotypique de l'homozygote; $d$ : déviation de dominance) et de la déviation standard commmune $(0.79 \mathrm{~kg})$. La ligne verticale sépare la conformation normale (à gauche) de la conformation culard (à droite).

The degree of overlapping of the distributions corresponding to the genotypes $m h /+$ and $m h / m h$ is quite small and of the order of 2 p. $100(2 \times 1,12$ p. 100). The heterozygote $(m h /+)$ is near the homozygous normal $(+/+)$ and the proportion of overlapping of these two genotypes amounts to 23.4 p. $100(2 \times 11.7$ p. 100$)$. These latter 2 genotypes exhibit the conventional conformation (fig. 3 - area at the left of the vertical line) while the homozygote $m h / m h$ has a distinct conformation although with varying degrees as can be inferred from the variation of the muscle weight within this class (fig. 3 - area at the right of the vertical line). 
Our results support the hypothesis of a single partially recessive gene put forward previously, but on the basis of subjective data, by authors as MAGLIANo (1933), Weber \& IbSEN (1934), KidWell et al. (1952), Hanset (1967, 1972), Rollins et al. (1972), (see the review by MENissier, 1982).

Received October 1st, 1984.

Accepted February 27, 1985.

\section{Acknowledgements}

Drs M. Ansay, C. Hanzen, M. Jandrain, K.N. Kintaba, P. Leroy and J. Marcourt are thanked for their valuable assistance. The technical skill of Mr A. BreULS DE TIECKEN and of Miss J. RoupaIN has been greatly appreciated. The 2 referees are thanked for their constructive suggestions.

\section{References}

DuRbin J., 1961. Some methods of constructing exact tests. Biometrika, 48, 41-55.

HANSET R., 1967. Le problème de l'hypertrophie musculaire ou caractère «culard 》 dans la race bovine de Moyenne et Haute Belgique. Ann. Méd. Vét., 111, 140-180.

HANSET R., 1972. L'interférence du caractère culard et de la sélection basée sur la conformation dans la race bovine de Moyenne et Haute Belgique. Ann. Méd. Vét., 116, 27-56.

HANSET R., 1982 a. Muscular hypertrophy as a racial characteristic : the case of the Belgian Blue Breed. In : KING J.W.B. and MENISSIER F. (ed.), Muscle hypertrophy of genetic origin and its use to improve beef production, 437-449. Martinus Nijhof, The Hague.

HANSET R., 1982 b. Major genes in animal production. Examples and perspectives : cattle and pigs. 2nd World Congress of Genetics Applied to Livestock Production. Madrid, 4-8 October, 1982, 6, 439-453. Editorial Garsi, Madrid.

Kaplan E.B., Elston R.C., 1978. A subroutine package for Maximum Likelihood Estimation (MaxLik). Dept. of Biostatistics. Univ. North Carolina, Chapel-Hill, Institute of Statistics. Mimeo Series $\mathrm{n}^{\circ} 823$.

Kidwell J.F., Vernon E.H., Crown R.M., Singletary C.B., 1952. Muscular hypertrophy in cattle. J. Hered., 43, 62-68.

Magliano E., 1933. Indagni circa il comportamiento genetico della cosidetta "groppa di cavello 》 nei bovini di razza piemontese. Clinica Vet. Milan, 11, 124-139.

Menissier F., 1982. Present state of knowledge about the genetic determination of muscular hypertrophy or the double-muscled trait in cattle. In : KING J.W.B. and MeNISSIER F. (ed.), Muscle hypertrophy of genetic origin and its use to improve beef production, 387-428. Martinus Nijhof, The Hague.

Merat P., 1967. Moyens possibles de déceler des gènes influant sur la variance phénotypique. Ann. Biol. Anim. Bioch. Biophys., 7, 489-493.

Merat P., 1968. Distributions de fréquences, interprétation du déterminisme génétique des caractères quantitatifs et recherche de «gènes majeurs 》. Biometrics, 24, 277-293.

Rollins W.C., Tanaka M., Nott C.F.G., Thiessen R.B., 1972. On the mode of inheritance of double muscled conformation in bovines. Hilgardia, 41, 433-456.

ShapIRo S.S., WILK M.B., 1965. An analysis of variance test for normality (complete samples). Biometrika, 52, 591-611.

SNedecor G.W., Cochran W.G., 1980. Statistical Methods, 7th ed., The Iowa State University Press, Ames, Iowa, U.S.A. 
Statistical ANalysis System (SAS). SAS user's guide 1979. SAS Institute Inc., Cary, North Carolina.

STEPhEns M.A., 1974. E.D.F. (Empirical Distribution Function) statistics for goodness of fit and some comparisons. J. Am. Stat. Ass., 69, 730-737.

Weber A.D., IbSen H.L., 1934. The occurrence of the double muscle character in pure-bred beef cattle. Proc. Amer. Soc. Anim. Prod., 27, 228-232.

\section{Appendix}

\section{Estimation by Weighted Least Squares of gene effect and dominance deviation}

The residual Sum of Squares corresponding to the expectations of table 2 (see text) is given by :

$$
\begin{aligned}
& \sum_{\mathrm{i}}\left(\mathrm{X}_{i}-\mu+\mathrm{m}+\mathrm{a}\right)^{2}+\sum_{\mathrm{i}}\left(\mathrm{X}_{j}-\mu-\mathrm{m}-\mathrm{a}\right)^{2} \\
+ & \sum_{\mathbf{k}}\left(\mathrm{X}_{k}-\mu-\mathrm{d}\right)^{2}+\sum_{1}\left(\mathrm{X}_{l}-\mu-\mathrm{m} / 2-\mathrm{d}\right)^{2} \\
+ & \sum_{\mathrm{m}}\left(\mathrm{X}_{m}-\mu-\mathrm{m} / 2-\mathrm{a}\right)^{2}
\end{aligned}
$$

From the partial derivatives of this sum with respect to the 4 unknowns : $\mu, \mathrm{m}$,

\begin{tabular}{|c|c|c|c|c|}
\hline \multicolumn{4}{|c|}{ Left Hand Member (LHM) } & \multirow{2}{*}{$\begin{array}{c}\text { Right Hand } \\
\text { Member (RHM) }\end{array}$} \\
\hline$\mu$ & $\mathrm{m}$ & a & d & \\
\hline $\mathrm{n}_{i}+\mathrm{n}_{j}+\mathrm{n}_{k}+\mathrm{n}_{l}+\mathrm{n}_{m}$ & $\begin{array}{c}-\mathrm{n}_{i}+\mathrm{n}_{i}+1 / \Sigma \mathrm{n}_{l} \\
+1 / 2 \mathrm{n}_{m}\end{array}$ & $-\mathrm{n}_{i}+\mathrm{n}_{i}+\mathrm{n}_{m}$ & $\mathbf{n}_{l}+\mathbf{n}_{l}$ & $\begin{array}{l}\Sigma X_{i}+\Sigma X_{i}+\Sigma X_{l} \\
+\Sigma X_{l}+\Sigma X_{m}\end{array}$ \\
\hline$-\mathrm{n}_{i}+\mathrm{n}_{j}+1 / 2 \mathrm{n}_{l}+1 / \Sigma \mathrm{n}_{m}$ & $\begin{array}{l}\mathrm{n}_{i}+\mathrm{n}_{i}+1 / 4 \mathrm{n}_{l} \\
1 / 4 \mathrm{n}_{m}\end{array}$ & $\mathrm{n}_{i}+\mathrm{n}_{i}+1 / 2 \mathrm{n}_{m}$ & $1 / \Omega \mathrm{n}_{l}$ & $-\underset{1 / 2 \Sigma X_{l}+1 / 2 \Sigma X_{m}}{\Sigma}$ \\
\hline$-\mathrm{n}_{i}+\mathrm{n}_{i}+\mathrm{n}_{m}$ & $\mathrm{n}_{i}+\mathrm{n}_{i}+1 / 2 \mathrm{n}_{m}$ & $\mathrm{n}_{i}+\mathrm{n}_{i}+\mathrm{n}_{m}$ & - & $-\Sigma X_{i}+\Sigma X_{j}+\Sigma X_{m}$ \\
\hline $\mathrm{n}_{k}+\mathrm{n}_{l}$ & $1 / 2 \mathrm{n}_{l}$ & - & $\mathbf{n}_{k}+\mathbf{n}_{l}$ & $\Sigma \mathbf{X}_{k}+\Sigma \mathbf{X}_{l}$ \\
\hline
\end{tabular}
a, $d$, the following set of Least Squares equations is obtained $\left(n_{i}, \ldots n_{m}\right.$ are the numbers of individuals in each genetic class).

The residual variance, $\sigma^{2}{ }_{e}$ considered as being the same for all classes, is computed from the residual Sum of Squares and the standard errors of the estimates are given by $\sigma_{e} \sqrt{C^{i i}}$ where $C^{i i}$ is the corresponding diagonal elements in the inverse matrix. 